Q.-K. KANG, L. WANG, Q.-J. LIU, J.-F. LI, Y. TANG* (SHANGHAI INSTITUTE OF ORGANIC CHEMISTRY AND COLLABORATIVE INNOVATION CENTER OF CHEMICAL SCIENCE AND ENGINEERING, TIANJIN, P. R. OF CHINA)

Asymmetric $\mathrm{H}_{2} \mathrm{O}-\mathrm{Nucleophilic}$ Ring Opening of D-A Cyclopropanes: Catalyst Serves as a Source of Water J. Am. Chem. Soc. 2015, 137, 14594-14597.

\title{
Copper-Catalyzed Asymmetric Ring Opening of D-A Cyclopropanes
}

\section{Category}

Metal-Catalyzed Asymmetric

Synthesis and

Stereoselective

Reactions

\section{Key words}

ring opening

cyclopropanes

copper

asymmetric

catalysis
$\underbrace{\mathrm{CO}_{2}(2-\mathrm{Ad})}_{\mathrm{CO}_{2}(2-\mathrm{Ad})}$

$\underset{\mathrm{DME}, \text { r.t. }}{\stackrel{\mathrm{Cu}\left(\mathrm{ClO}_{4}\right)_{2} \cdot 6 \mathrm{H}_{2} \mathrm{O} / \mathrm{L}(15 \mathrm{~mol} \%)}{\longrightarrow}}$<smiles>[R]C(O)CC(COC(=O)OCc1ccccc1)C(=O)OCc1ccccc1</smiles>

Selected examples:<smiles>COc1ccc([C@@H](O)CC(C(=O)OCc2ccccc2)C(=O)OCc2ccccc2)cc1</smiles>

$95 \%$ yield

$93 \%$ ee<smiles>CC(C)(C)COC(=O)OCC(=O)OCC(O)CC(O)C=Cc1ccccc1</smiles>

$95 \%$ yield

$87 \%$ ee<smiles>COc1ccc(C(O)CC(C(=O)OCc2ccccc2)C(=O)OCc2ccccc2)cc1OC</smiles><smiles>O=C(COC(=O)C(O)CC(O)c1cccs1)OCc1ccco1</smiles>

$91 \%$ yield $82 \%$ ee
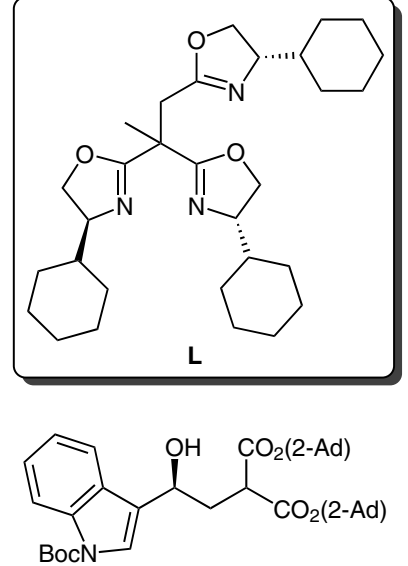

$96 \%$ yield $87 \%$ ee

Effect of the water loading:



Significance: The authors report a copper-catalyzed enantioselective ring-opening reaction of donor-acceptor cyclopropanes with water. A variety of ring-opening products were obtained in high yields ( $\leq 96 \%)$ and enantioselectivities $(\leq 95 \%$ ee).

SYNFACTS Contributors: Hisashi Yamamoto, Masahiro Sai Synfacts 2016, 12(2), $0171 \quad$ Published online: 19.01.2016 Dol: 10.1055/s-0035-1561173; Reg-No.: H18015SF
Comment: In this reaction, the copper hydrate serves as both a Lewis acid and a source of water; this affords a system for the controlled release of the appropriate amount of water as a nucleophile in the asymmetric catalysis. The method provides a new and efficient approach for direct access to $\gamma$-substituted $\gamma$-hydroxybutyric acid derivatives. 